Steric Course of Microbiological Reactions

Edited by G. E. W. Wolstenholme and Cecilia M. O'Connor. (Ciba Foundation Study Group, No. 2.) Pp. viii +115. (London: J. and A. Churchill, Ltd., 1959.) 12s. $6 d$. net.

I HE volumes describing the proceedings of the three-day and four-day conferences arranged by the Ciba Foundation are well known, and they have firmly established themselves as an important guide to current research in the sciences allied to medicine. This little book represents a new venture, namely, publication of the proceedings of a one-day study group. It contains five communications, preceded by an introduction by the chairman (A. Neuberger). The first (by F. H. Westheimer) is a historical review of the steric course of microbiological reactions. This is followed by articles on the mechanism of hydrogen transfer with pyridine nucleotides (K. Wallenfels), steric mechanisms in reactions of lactic acid (N. O. Kaplan), and the steric and molecular specificity of steroid dehydrogenases (P. Talalay and H. R. Levy). The final communication, on the steric course of some microbiological and enzymic reductions of ketones, is by Prof. V. Prelog of Zurich, in whose honour this particular study group was organized.

These papers deseribe different aspects of an exciting and rapidly advancing branch of enzyme research, one which is of importance to biochemists and organic chemists alike. They are presented with great clarity, in spite of the complexity of the subject. They could be read and enjoyed by final-year honours students as well as by postgraduate workers, and for this reason the low price of the book is especially welcome. The papers are well illustrated with chemical structures, curves of reaction rates, diagrams of suggested means of attachment of enzymes to their coenzymes and substrates, and so on, and they are accompanied by a detailed account of the discussions which followed. According to the preface, the publishing of the first four of these one-day study group conferences is regarded as an experiment. Judging by this sample, the experiment must be considered highly successful. It is greatly to be hoped that these stimulating accounts of the work of the study groups will continue to appear from time to time, together with the volumes of the longer conferences.

D. C. HARRISON

\section{Milk Testing}

The Laboratory Control of Milk. By Dr. J. G. Davis. second edition. Pp. xiv +309 . (London: Dairy Industries, Ltd., 1959.) $30 s$.

7

HIS book is intended to provide all the necessary information for the routine control of milk by those concerned with laboratory work in collecting depots and processing dairies. It is therefore in the nature of a selection of standard methods for the sampling and chemical and bacteriological examination of milk for use in the dairy industry. The author has collected a great deal of information into a small publication. The sections dealing with the sampling of dairy products and the organization of the dairy laboratory are very good, but the author is at his best when dealing with the bacteriological tests. The section dealing with chemical tests might be criticized because it consists to a very large extent of reprints of British Standards specifications, which are readily available from other sources. The section dealing with the calibration of glassware-a basic need in any dairy laboratory-is dealt with very scantily and is not given sufficient attention.

The publication would be a valuable addition to the library of any dairy laboratory, and provides an easy means of reference to some of the more rarely used techniques which may be required for special investigations. However, the author does not deal fully with these methods, but all too often only provides references which will be difficult to obtain in the type of laboratory where the book will be of greatest use. The book is well printed, on the whole well written, and very free of mistakes. The most serious error is on p. 86 , where it is stated that the total nitrogen is automatically determined when the casoin is estimated.

A. L. Provan

\section{A Supplement to "Helium"}

By E. M. Lifshits and E. L. Andronikashvili. Translated from the Russian. Pp. v 167. (Now York: Consultants Bureau, Inc.; London: Chapman and Hall, Ltd., 1959.) 7.50 dollars; $60 \mathrm{~s}$.

$\mathrm{O}$ $\mathrm{NE}$ gets the curious impression, on reading this book, that one has been here before, and then one realizes that although the book has only now appeared in English translation, it was actually written in 1949 . In other words, it was written, from its notions about liquid helium, in pre-Feynman days, and from its style and ethos, in the days of Stalin.

The great virtue of Keesom's "Helium" is that it contains every measurement made and every idea expressed on helium, good, bad, and indifferent, from the year one up to near the year 1942, when the book was published. All the ideas were allowed to find their own level with only the gentlest help from the author. Thus the book has an abiding value in spite of its appearance before the Landau theoretical break-through in the mid-'forties and the Feynman theoretical break-through in the mid-'fifties.

The "Supplement to Helium" is entirely different in character. It is a Russian view of the work done on liquid helium during the late 1930's and the 1940's when the Russian contribution was undeniably outstanding, but it was written at a time when it was apparently politically necessary to make it appear that non-Russian efforts were at best confused and at worst wrong-headed. The present reviewer gets off rather lightly in having his work deseribed as "carried out under very complicated conditions . . ." ", but Tisza, whose contributions to the theory of helium-II have been of very great importance, is treated very unfairly indeed. A decade ago one could sympathize with Russian colleagues who were in a difficult position, but it would have been an act of grace on the part of the authors if they had modified the text prior to its present translation. As it is, the repeated slanging somewhat mars an otherwise quite useful addition to the literature on liquid helium.

From the point of view of readability, appearance and accuracy the book is no great advertisement for either the Consultants Bureau or for the "multilith process from the International Business Machines, Ltd., 'cold' type". The printing is uneven and there are many blemishes, the mathematical type-setting is poor, the references in the text to figures and equa. tions are sometimes wrong, and there are other proof errors such as Michels's name appearing as Milelson on p. 100 .
J. F. Alten 